Pakistan Journal of Humanities \& Social Sciences Research Volume No. 02, Issue No. 01(June, 2019)

\title{
"MYTHS AND REALITIES OF MICROFINANCE AS A PANACEA FOR EMPOWERMENT"
}

\author{
Kausar Yasmeen*, Kashifa Yasmeen** \& Mustafa Malik $†$
}

\begin{abstract}
The main aim of this study is to examine the influence of microfinance involvement on women's empowerment. By using the questionnaire, 744 respondents were selected through simple random sampling methods to collect the data from non-borrowers and borrower's women of National Rural Support Program (NRSP) and Khushhali Bank (KB) in Bahawalpur, Pakistan. This study applied the cross-sectional data and applied multinomial Logit to achieve its objectives. The findings reveal that the women who have microfinance are more empower relative to those who do not avail the microfinance so the coefficient of the loan size hike up women's empowerment of movement. It is also revealed that there is no significant role of the English language on women's empowerment of movement. Educated women are more empowered. This paper contributes socially and economically.

Keywords: microfinance, empowerment, multinomial Logit, language

\section{Introduction}

Male dominant society exists in Pakistan, especially inside the rural regions. Usually, the man limits woman's freedom of movement. Women confront social and cultural hurdles to have their proper physical movement. To be impartial, it's is argued that women want to involve themselves in economic activities. However, loss of finance is the essential

*Department of Economics and Finance Nizwa university, Oman Email: yasmeen@unizwa.edu.om

**Department of Psychology University of Lahore Email: Kashifa.psy@gmail.com

† Department of Business Management Nizwa university, Oman Email: mustafamalik@unizwa.edu.om
\end{abstract}


problem that discourages females to get involved in financial matters. Relative to females in rural areas, females in town areas have especially clean get entry to casual assets of credit score like cash lender, friends, and loved ones but, they might charge high rate of hobbies (TLO, 1998). Noreen (2011) found if females are allowed to go for small businesses they can contribute their income to their households.

Microfinance is a type of economic support that objectifies particularly females. UN is permuting microfinance via investment to achieve the purpose of female's empowerment. Microfinance entails women in the microbusiness company and one-of-a-kind money generating tasks that would empower females. Khushali Bank is one kind of microfinance bank such banks are helping the poor females in Pakistan. There are busy in enhancing females in the corporation, however, it isn't always positive whether or no longer these monetary organizations micro-credit score rating microfinance programs have helped the females' financial desire to make them empower. In sum, evaluating microfinance scheme is the important issue. It has an excessive satisfactory impact on poor women or the strive of $\mathrm{UN}$ is vain because, few researches report that, guys take the loan on the names in their females, so, the corporation's cause to directly finance females fails. Some researchers discovered females fail to hold monetary sports because of immoderate charge of interest. In this connection, numerous researchers have studied the general effect of microfinance on female's empowerment. The consequences are mixed. Several researches show that microfinance has a satisfactory impact on females' empowerment (Banu et al., 2000) on the same time as a few studies display that microfinance in Lahore, Pakistan has insignificant influence on the women's empowerment (Asim, 2008).

Traditionally, a female's lifestyle in Pakistan, within this tradition, the right of superior expertise in Urdu or English has no price. Women in lots of parts of Pakistan may additionally get two or three years of number one education, with a wonderful strain on home obligations and spiritual texts. However, they are discouraged from pursuing something at a better level. Upper-elegance women get possibilities to observe as tons as they need, however, their variety is very small. As the reputable corresponded is favoured in English language 
(Shah, 2015). However, the researcher failed to discover the impact of English language on women's freedom of movement In Pakistan, get entry to English is very limited. Until these days, the learning of English in Pakistani government schools usually starts in Class Six. This overdue start facilitates us to apprehend the sensible predicament of women to basic lowdegree literacy in Urdu, with possibly a few publicities to Arabic. It additionally manner their practical exclusion from the sector of English, a global which gives possibilities for further boom and development in medicine, technological know-how, psychology, sociology and technology. They are pressured to research Urdu but not learning well sufficient. This is genuine however; it has been modified among middle elegance. We are given the significance of Urdu inside the political context, but an evaluation suggests that only a few steps have been taken to modernize Urdu.

Moreover, capabilities can be acquired more without difficulty and appropriately in a single's mother tongue, but if that tongue has not been developed, it may act as a hindrance. We commonly see in Pakistan a form of stillness and immobility, contrary to the movement and development of different elements of the world. In the start, a super deal of translation from English is needed, to be accompanied with the aid of extreme studies, technological know-how and technological development. Presently, we rely on English for better education to a splendid volume. A woman in Pakistan has to be in a position in it, or she is constrained to the restrictive roles as recognized earlier (Shah, 2015). The restrictive roles and language stasis are significantly stricken by the social elements which help us to apprehend the conventional lifestyle of the area.

\section{Literature Review}

There is numerous research that analyzes the influence of microfinance on the empowerment of females. Asim (2008) found the insignificant influence of microfinance on the bargaining energy of females in the household making selections which incorporate child associated, health, economic and social mobility. Women are less empowered in making the vital choice which encompasses decisions regarding residence repair and sale/purchase of the residence. These choices commonly fall inside the region of 'male-first-rate' selections in patriarchal societies.

Chaudary and Nosheen (2009) state that microloan 
positively influences women empowerment. Cheston and Kuhn (2002) examine the role of microfinance applications on women's empowerment; own family planning and cultural norms.

They finish that microfinance programs have a huge impact on empowerment and women's rights. It is critical to cautiously examine whether or not microfinance has a high-quality effect on poor women. Opening doorways to English and higher education for women has had and could have a huge trickledown impact on Pakistani society in popular. Traditional norms can be challenged; however, if the movement is largely inside the fingers of women, this will possibly happen non-violently. If it is restrained to men, it's going to either in no way take region, or may result in disagreement and violence (Shah, 2015). So, there can be a threat, the woman who can speak or write English probably has greater freedom owing to having the ability to the verbal and written conversation in English.

Empowering women is a vital however not the excellent assignment of microfinance (Kabeer, 2001). Non-monetary controlling additives of microfinance, though, is significant a great manner to manipulate functionality excellent outcomes, together with because of own family-primarily based micro financing businesses (Maldonado \& Gonza'lez-Vega, 2008) or the risk of over-indebtedness. Several scholars introduced methods to measure the microfinance (Weber, 2013), it's miles nonetheless unsure how consequences of microfinance can be evaluated. The use of case studies without manipulating organizations isn't successful to analyse cause-effect members of the family in evaluation to govern-institution studies much like the only by using way of Chowdhury and Chowdhury (2011).

Age is a vital demographic feature which affects female's empowerment. With the passage of time, revel in increases and clever decisions include experience. Hence, age has impacted on improving the empowerment and happiness of women. Mason (1986) argued that females' conduct differs at some stage in the ranges inside the life cycle. It is likewise desired with the aid of the Noreen (2010), Handy and Kassam (2004), and Mustafa et al., (2008).

Education has influences on female's empowerment and happiness as education outcomes in expertise and expertise opens doors of information that bring about immoderate empowerment. Hence, education has been talked about as a key indicator of empowerment with the aid of diverse kinds of 
literature (Malhotraet al. 2002). Several variables have been traditionally used as proxies for empowerment, which includes schooling and employment; these are well described as "allowing factors" or "assets of empowerment" (Kishor, 2000). Empowerment also includes mental and cognitive elements, along with a woman's records of her scenario of subordination and the motives of such activities. This desires important knowhow approximately self, social and cultural expectations, which can be enabled through training (Stromquist, 1995).

Independent variables

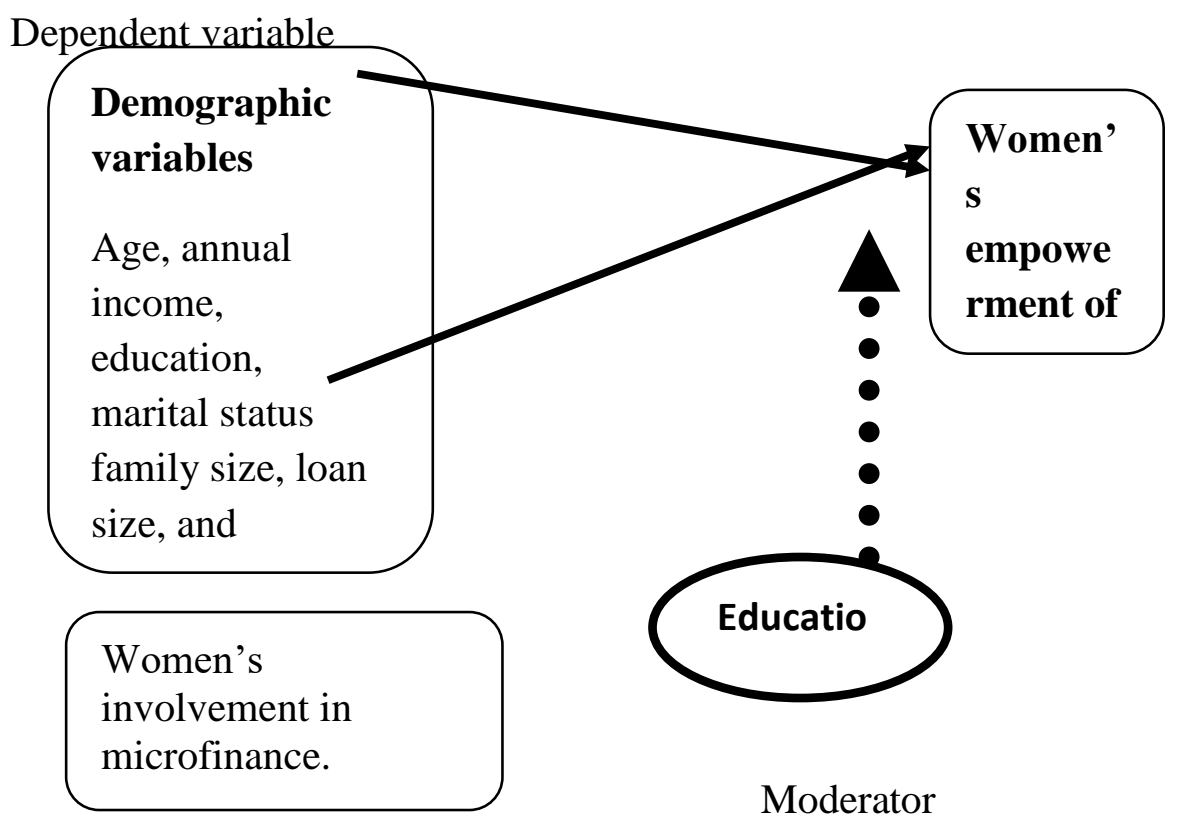

Figure: 1.1 conceptual model of the study

Hasherni et al. (1996), Parveen (2007), Hashemi et al. (1996), Banu et al. (2000), Becchetti (2009) and Bandyopadhyayet al. (2011) look at the effect of microfinance on females empowerment and happiness. Lastly, within the case of feminist empowerment paradigm, profits will boom in women's status and enhance the capacity to barter changes in the relation of gender. Subsequently, rising income and jobs possibility and capacity to exchange modifications in gender relation will increase movement and information of social, crook and political issues.

Parveen (2007) Hashemi et al. (1996) Banu et al. (2000), Becchetti (2009) and Bandyopadhyayet al. (2011) use the mortgage length to look at the effect of microfinance on 
females empowerment and happiness due to the truth if a girl has a larger loan duration she can start an excellent corporation and might earn greater. However, on this look at, we use the liberty of movement as a few established variables, demographic variables; microfinance involvement and loan duration are used as an unbiased variable. Shah (2015) found that females who can communicate English can have more empowerment. The variable education is taken as a moderator variable as shown in figure 1.1

\section{Econometric Model of the Study}

We will estimate equations, the MF (microfinance involvement)and English language are measured in dummies. $\mathrm{Y}_{1}=\beta_{0}+\beta_{1}$ Age $_{\mathrm{i}}+\beta_{2}$ edu $_{\mathrm{i}}+\beta_{3}$ Fsize $_{\mathrm{i}}+\beta_{4}$ Annual $_{\mathrm{i}}+\beta_{5} \mathrm{MS}_{\mathrm{i}}+$ $\beta_{6} \mathrm{MF}_{\mathrm{i}}+\beta_{7} \mathrm{EL}_{\mathrm{i}} \beta_{8}(\mathrm{MFi} * \mathrm{edu})_{\mathrm{i}}+$ ei.

This study used the multinomial Logit model to estimate the effect of microfinance on women's empowerment. The structured variable women's freedom of movement empowerment is measured in 3 categories " 0 ", " 1 " and " 2 ". All the control variables are measured in dummy variables. 0 suggests to unmarried women and to females who aren't contained in microfinance and 1 suggests to married women who're involved in microfinance.

\subsection{Data Collection Strategies}

The cross-sections is gathered through a questionnaire. Data on women empowerment was accumulated from types of women: non-borrowers and customer's women of National Rural Support Programmed and Khushhali Bank. Questionnaire of Pitt, Khandker and Cartwright (2006) is adopted. A stratified random sample of 744 households was drawn 372 questionnaires have been filled by woman customers of National Rural Support and Khushhali Bank while 372 questionnaires have been filled by non-borrowers.

\section{Descriptive statistics}

According to the Table 1, the average age of women borrowers ranges from 17 to 75 . In the case of non-borrowers, the average age is 40 . The minimum age is 18 and maximum age is 75 . In the case of education, the average years of education of women borrower is 2 while for the women non borrower the average years is 0 of education. In the case of family size the average for women borrowers is 6.57 while for the women non-borrower, the average of family size is 5.91. The average income of women borrowers is 3000 while average income of the women non-borrowers is 0 . 
Table: 1 Descriptive statistics of variables

\begin{tabular}{|c|c|c|c|c|c|c|c|c|}
\hline \multicolumn{4}{|c|}{ Borrowers } & \multicolumn{5}{|c|}{ Non-borrowers } \\
\hline & $\begin{array}{c}\text { M } \\
\text { ea } \\
n\end{array}$ & $\begin{array}{c}M \\
\text { in } \\
i\end{array}$ & $\begin{array}{c}\mathrm{Ma} \\
\mathrm{x}\end{array}$ & $\begin{array}{c}\text { Std. } \\
\text { devia } \\
\text { tion }\end{array}$ & $\begin{array}{c}\mathrm{M} \\
\mathrm{ea} \\
\mathrm{n}\end{array}$ & $\begin{array}{c}\bar{M} \\
\text { in } \\
\mathrm{i}\end{array}$ & $\begin{array}{c}\mathrm{M} \\
\text { axi }\end{array}$ & $\begin{array}{l}\text { Std } \\
\text {.devi } \\
\text { ation }\end{array}$ \\
\hline Age & $\begin{array}{l}37 . \\
41\end{array}$ & $\begin{array}{l}1 \\
7\end{array}$ & 75 & 11.057 & $\begin{array}{l}39 . \\
97\end{array}$ & $\begin{array}{l}1 \\
8\end{array}$ & 75 & $\begin{array}{c}12.81 \\
3\end{array}$ \\
\hline $\begin{array}{l}\text { Educ } \\
\text { ation }\end{array}$ & $\begin{array}{c}1.7 \\
6\end{array}$ & 0 & 14 & 3.557 & .42 & 0 & 16 & 1.848 \\
\hline $\begin{array}{c}\text { Fami } \\
\text { ly } \\
\text { Size }\end{array}$ & $\begin{array}{c}6.5 \\
7\end{array}$ & 0 & 15 & 2.629 & $\begin{array}{c}5.9 \\
1\end{array}$ & 0 & 21 & 2.790 \\
\hline $\begin{array}{c}\text { Annu } \\
\text { al } \\
\text { Inco } \\
\text { me }\end{array}$ & $\begin{array}{l}5 . \\
74\end{array}$ & $\begin{array}{l}3 \\
0 \\
0 \\
0\end{array}$ & $\begin{array}{c}8,4 \\
000 \\
0\end{array}$ & $\begin{array}{c}6447 \\
3.054\end{array}$ & $\begin{array}{c}1.8 \\
6\end{array}$ & 0 & $\begin{array}{l}180 \\
000\end{array}$ & $\begin{array}{c}33484 \\
.209\end{array}$ \\
\hline
\end{tabular}

\subsection{Empirical results}

The hypothesis is women who are involved in those micro-credit score applications could be greater empowered in freedom of movement. The multinomial logit model turned into used to study the impact of microfinance on women's freedom of movement. Later, we will additionally talk about the estimation results of the multinomial probit model to decide whether or not our effects are sturdy to unique estimation. In this primary model, freedom of movement empowerment is the dependent variable at the same time as age, respondent's education, family length, respondent's annual income, marital popularity, involvement in microfinance and interaction term between training and microfinance are taken because of the impartial variables. Hence we additionally consist of the interaction time period between microfinance and schooling as one of the unbiased variables.

Table 2 affords the outcomes of the multinomial logit model estimation. The result indicates that in every so often freedom relative to no freedom, the variable microfinance involvement is effective and massive at 1 percentage indicating 
a fantastic effect on women's freedom of movement. In complete freedom relative to no freedom, the variable microfinance involvement is likewise distinctly giant at 1 percentage and undoubtedly associated with the empowerment of movement. Hence, each instance, the involvement of women in microfinance positively affects women's movement. This can be defined as follows. The non-borrowers commonly stay in-door and experience hesitation to visit banks, markets, or to different villages. Usually, they need to get permission to go outside and if authorized, occasionally a male family member accompanies them. On the opposite hand, women's debtors go out-door for their commercial enterprise cause. This complements their confidence to go out of doors by way of going to banks, markets, and other locations on their own. Usually, they don't want to get permission to go outdoors just like the non-borrowers. Nessa (2011) located that Involvement with MFI is a considerable predictor of freedom of movement of swomen empowerment. By related to MFI they have an extra role in physical mobility. By using their mortgage for microcommercial enterprise, their earnings will increase that in the end improves their freedom of movement. The effects of the take a look at are similar to Swain (2007b), Kavitha (2007), Cheston and Kuhn (2002), Mayoux (1997), Hunt and Kasynathan (2002), Mayoux (2006), Hasherni et al. (1996),Parveen(2007), Banu et al. (2000), Noreen (2011). This examines found that there's no impact of English language on women's freedom of movement, this could be given an explanation for as follows because the records are collected from Bahawalpur Division of Pakistan wherein Urdu, Punjabi and Suraiki languages are used for communiqué. The dealers typically communicate in the three stated languages. So, due to the absence of multicultural presence in Bahawalpur, there is no effect of English language on women's freedom of movement.

The coefficient education is positive and significant in the case of full freedom relative to no freedom. The results indicate that education has a positive effect on women's freedom of movement. Since more educated women are free than uneducated women. The result could be because educated women practice to go to school (outdoor) from their childhood. Later they get habituated and feel free to go out. So, she would become confident and free because of her social network in class and survival. Coefficient of education is not significant in 
the case of sometimes freedom relative to no freedom. The coefficient of the interaction term between education and microfinance is not significant, indicating that the effect of microfinance and education on freedom of movement empowerment does not depend on the level of education. The result could be because most of the women in our sample are illiterate.

The coefficient of age is not significant in the case of sometimes freedom relative to no freedom. A little girl can face difficulties if she goes out-door because of her lack of maturity and interaction with people. As the woman's age increases, she experiences many things and become more mature. This experience and maturity leads her to go outside. Coefficient of the family size variable is positive and significant in both sometimes freedom and full freedom compared to no freedom, indicating that family size has a positive effect on woman's freedom of movement. A large family size enables household members to take care of one another's rights and have more respect towards women. The coefficient of variable income is positive and significant in both sometimes freedom and full freedom compared to no freedom.

Table 2: $\quad$ Results of Multinomial Logit Model Estimation.

\begin{tabular}{|c|c|c|c|c|}
\hline & \multicolumn{2}{|c|}{$\begin{array}{l}\text { Sometimes } \\
\text { freedom relive to } \\
\text { No freedom }\end{array}$} & \multicolumn{2}{|c|}{$\begin{array}{l}\text { Full freedom relive to } \\
\text { No freedom }\end{array}$} \\
\hline Variables & Coef. & Std. Err. & Coef. & Std. Err. \\
\hline Age & 0.00 & 0.02 & $.035 * * *$ & 0.02 \\
\hline Education & 0.06 & 0.09 & $.289 * * *$ & 0.07 \\
\hline Family size & $.086 * *$ & 0.05 & $.075 * *$ & 0.04 \\
\hline Income & $4.48 * * *$ & 3.85 & $.000 * * *$ & 0.00 \\
\hline $\begin{array}{l}\text { Marital } \\
\text { status }\end{array}$ & 0.39 & 0.45 & $.856^{* * * *}$ & 0.39 \\
\hline $\begin{array}{c}\text { Microfinance } \\
\text { involvement }\end{array}$ & $.931 * * *$ & 0.32 & $1.432 * * *$ & 0.30 \\
\hline $\begin{array}{c}\text { English } \\
\text { Language }\end{array}$ & 0.49 & 0.55 & 0.07 & 0.08 \\
\hline edu* MFI & 0.00 & 0.00 & 0.00 & 0.00 \\
\hline _cons & -3.49 & 0.64 & -4.731 & 0.59 \\
\hline Prob > chi2 & $=0.0000$ & \multicolumn{3}{|c|}{ Log likelihood $=-792.106$} \\
\hline
\end{tabular}


Note: 0 (no ability) (base outcome). $* * * * *$ and $*$ indicate that variables are significant at $1 \%, 5 \%$ and $10 \%$ level of significance respectively. Sometimes freedom is the a base outcomes.

\subsection{Marginal effect of women's empowerment of movement}

First, the marginal impact of involvement in microfinance on the chance of complete freedom is massive. In unique, if a girl involves in microfinance the chance of full freedom is predicted to upward push via 21 percent, whilst the chance of getting occasionally freedom is predicted to upward thrust through 49 percent. The chance of no freedom is expected to fall via 26 percent.

Second, the marginal impact of respondents' training at the opportunity of getting the freedom of movement is vast for full capability best. In particular, if the schooling of a respondent increases by using one year, the possibility of getting complete freedom is expected to upward thrust by way of 27 percentage. The end result suggests that the possibility of being extra empowered in terms of freedom of movement increases with the degree of education. In once in while freedom, if the education of a respondent will increase by three hundred and sixty-five days, the opportunity getting occasionally freedom is predicted to fall by using 0 . Three percent and no freedom is predicted to fall via 2.6 percent.

Third, the marginal effect of respondent's age on the opportunity of getting the freedom of movement is enormous for complete freedom best. In precise, if the age of a respondent will increase through 365 days, the probability of getting full freedom of movement is expected to upward thrust by zero. 4 percentage. The end result indicates that women's empowerment in the time period of freedom of movement increases with age. These effects display that complete freedom appears to cater to older humans, while no freedom and from time to time freedom appear to be indifferent toward the age of the respondent. Fourth, in specific, if the quantity of family length increases by one from its mean price, the opportunity of having complete freedom is expected to upward thrust via zero. nine percent. On the alternative hand, the opportunity of having on occasion freedom is predicted to rise by way of 0 . Eight percent and the possibility no freedom is anticipated to fall by using 1.7 percentage. 
Fifth, the marginal impact of the once a year income of respondents on the possibility of having complete freedom and sometimes freedom is massive. In particular, if the amount of annual income of respondent increases through PKR: one thousand from its suggested cost of profits, the chance of getting complete freedom is predicted to upward push by 19 percent. The coefficient of earnings inside the possibility of having occasionally freedom is expected to upward thrust by using seventy-six percent. The possibility of no freedom is anticipated to fall by using 26 percent. If earnings increase through PKR: one thousand these results endorse that obtaining no freedom appears to be ensuing in exceptionally low profits at the same time as complete freedom and from time to time freedom is related to highly high income.

Table 3: Results of marginal Effect

\begin{tabular}{|c|c|c|c|}
\hline $\begin{array}{l}\text { Variable } \\
\text { (Y1) }\end{array}$ & No freedom & $\begin{array}{l}\text { Sometimes } \\
\text { freedom }\end{array}$ & Full freedom \\
\hline Age & $\begin{array}{l}-.0049766 \\
* * \\
(0.033)\end{array}$ & $\begin{array}{l}-.0020201 \\
(0.567)\end{array}$ & $\begin{array}{l}.0059967 * * * \\
(0.003)\end{array}$ \\
\hline Education & $\begin{array}{l}.0360694 * * * \\
(0.002)\end{array}$ & $\begin{array}{l}-.0023187 \\
(0.923)\end{array}$ & $\begin{array}{l}.037388 * * * \\
(0.001)\end{array}$ \\
\hline Family $\mathbf{S}$ & $\begin{array}{l}-.027119 * * \\
(0.033)\end{array}$ & $\begin{array}{l}.0090693 \\
(0.248)\end{array}$ & $\begin{array}{l}.0080498 \\
(0.277)\end{array}$ \\
\hline Income & $\begin{array}{l}-0.365 * * * \\
(0.010)\end{array}$ & $\begin{array}{c}0.869 * * \\
(0.020)\end{array}$ & $\begin{array}{l}0.292 * * * \\
(0.010)\end{array}$ \\
\hline $\begin{array}{l}\text { Marital } \\
\text { Status }\end{array}$ & $\begin{array}{r}-.541 * * \\
(0.048)\end{array}$ & $\begin{array}{l}-.003 \\
(0.977)\end{array}$ & $\begin{array}{l}.355 * * \\
(0.024)\end{array}$ \\
\hline $\begin{array}{l}\text { English } \\
\text { Language }\end{array}$ & $\begin{array}{l}-.2442598 * * \\
(0.039)\end{array}$ & $\begin{array}{l}-.0023742 \\
(0.878)\end{array}$ & $\begin{array}{l}.2446339 * * \\
(0.013)\end{array}$ \\
\hline mfi* & $\begin{array}{l}. \\
3685304 * * * \\
(0.010)\end{array}$ & $\begin{array}{l}.0592239 \\
(0.111)\end{array}$ & $\begin{array}{l}.3193064 * * * \\
(0.010)\end{array}$ \\
\hline
\end{tabular}

Note: The figures in parenthesis are p-values; $* * *, * *$ and* denote that the corresponding coefficient is significant at the 1\%, 5\% and 10\% level, respectively.

Sixth, the marginal impact of marital fame of respondent at the probability of getting complete freedom is substantial. In precise, if the respondent receives married, the chance of 
getting full freedom is expected to upward thrust by using 14 percent. The marginal effect of marital reputation at the probability of getting on occasion freedom isn't always sizable. The chance of having now and again freedom and no freedom is predicted to fall by zero. 1 percent and 14 percent, respectively. If the respondent receives married, outcomes advise that no freedom seems to be associated with single women while the overall freedom is related to married women.

\section{Conclusion of women's freedom of movement empowerment}

The present study has analysed various aspects of microfinance including the theoretical framework and evolution of microfinance, basic methodological issues, impact studies, rural credit in Pakistan. This study concludes that microfinance alone cannot succeed as an intervention targeting the poor unless accompanied by efforts to address livelihoods and empowerment in some comprehensive manners. By using questionnaire present study collects the cross sectional data from 744 women living in Pakistan. By applying multinomial regression model, it is revealed that the coefficient of microfinance is significant and is positively related to women's freedom of movement. The coefficient of education is also positive and significant. This indicates that education positively affects women's freedom of movement. The coefficient of family size is significantly related to women's freedom of movement. The income, age and marital status also are variables that are found positive and significant. This study recommends that future studies should compare the profit by taking formal and tacit knowledge. This study also recommends that strategies should be adopted within the larger social frameworks which involves sensitization and shifts in the approached towards women role and rights.

\section{Bibliography}

Ai C, Norton EC (2003) Interaction Term in Logit and Probit Models. Economic Letters 80:123-129. The Stata Journal, 2004, 4(2):103-116.

Amin, R.; Becker, S.; and Bayes, A. (1998).NGO-Promoted Micro credit Programs and Women's Empowerment in Rural Bangladesh: Quantitative and Qualitative Evidence, The Journal of Developing Areas, Vol. 32, No. 2, pp. 221-36. 
Asim, S. A. (2008). Evaluating the Impact of Microcredit on Women's Empowerment in Pakistan, CREB Working Paper No.2- 9, Social Science Research Network.

Banu, D., Farashuddin, F., Hossain A., \&Akter, S. (2000), Empowering women in rural Bangladesh: Impact of BRAC's program.

Becchetti (2009). Microfinance and happiness, Working Paper No.69, Gennaio 2010

C1DA (2002). C1DA and Microfinance: A Poverty Reduction Approach Canadian International Development Agency, Policy Branch.

Carolyn, Hannan, (2003). Transforming Empowerment and Gender Mainstreaming, International Symposium on a new Vision for Gender Policy: Equality, Development and Peace. New York

Chaudary \&Nosheen (2009). The Determinants of Women Empowerment in Southern Punjab, Pakistan: An Empirical Analysis, European Journal of Social Sciences, Vol 10-2.pp.101-117

Cheston, S. and Lisa, K. (2002). Empowering women Through Microfinance, Washington: UN IFEM for Microcredit Summit, 2002.

De Gobbi, M.S. (2005). Nepal and Pakistan, Microfinance and Micro Development Their Contribution to the Economic Empowerment of Women, SEED Working Paper No. 69 ILO Geneva.

Farooq, O. M. (2009). The challenge of poverty and mapping out solutions: Requisite paradigm shift from a problemsolving and Islamic perspective, Journal of Islamic Economics, Banking and Finance, Volume-5 Number2, pp.45-76

Goetz, Anne Marie; and Gupta, RinaSen (1996). Who Takes the Credit? Gender, Power, and Control Over Loan Use in Rural Credit Programs in Bangladesh, World Development, Vol. 24, No. 1, pp. 45-63.

Government of Pakistan, (2004-05) Economic Survey of Pakistan, Islamabad, Ministry of Pakistan.

Handy, F. and Kassam, M. (2004), Women's empowerment in rural India. Paper presented at the ISTR conference, University of Toronto, Canada, july,2004

Hashemi, S. M., Schuler, S. R., \& Riley, A. (1996). Rural credit programs and women's empowerment in Bangladesh, World Development, Vol. 24, No. 4, pp. 635-653. 
Holvoet, N. (2005). The Impact of Microfinance on DecisionMaking Agency: Evidence from South India, Development and Change,Blackwell Publishing, Institute of Social Studies vol. 36 (1),pp. 75-102

Hoque, M., \&Itohara, Y. (2009). Women empowerment through participation in microcredit program: A Case study from Bangladesh. Journal of Social Science, Vol 5-3, pp 244-250

Human Development Report (1995), United Nations Development Programme, Oxford University Press, New York.

Hunt, J. and Kasynalhan,N.(2002). 'Reflections on microfinance and women's empowerment, Development Bulletin, No. 57, pp. 71-75

ILO (1998). Women in Informal Sector and Their Access to Microfinance, Inter-Parliamentary Union Annual Conference, Windhoek, Namibia, 2-11 April 1998

Kabeer and Naila (2001). Reflections on the Measurement of Women's Empowerment: In Discussing Women's Empowerment-Theory and Practice, Swedish International Development Agency, Stockholm, Sida Studies No. 3. NovumGrafiska AB: S, pp. 17-59

Kavitha,N. (2007). Role of Women IN Microfinance, SSM College of Engineering, Research report, Tamil Nadu, India.

Khandker, and Shahidur R. (1998). Fighting poverty with microcredit: Experience in Bangladesh. Report, Oxford University Press, October, 1998

Malhotra, A. Schuler S.R. and Boender, Carol, (2002): Measuring Women's Empowerment as a Variable in International Development, Background Paper for World Bank Workshop on Poverty and Gender: New Perspectives.

Mason, K.O. and Herbert L. Smith, (2003). Women's Empowerment and Social Context: Results from Five Asian Countries, The World Bank Washington D.C Rockefeller Foundation's Bellagio Study and Conference Center, 2 January 2003

Mayoux, L. (1997). The magic ingredient?Microfinace and women empowerment: Towards a Framework for Participatory Planning, Background Discussion Paper, ActionAid UK Washington, February 1997

Michael Pennock.(2006).The Gross National Happiness Abridged Survey, Population Health Epidemiologist, 
Vancouver Island HealthAuthority, Victoria, BC. Canada

Pakistan Microfinance Network (2003) .Performance indicators Report, Pakistan Microfinance Network Secretariat, Islamabad.

Parveen, S. and Ingrid- Ute Leohauser, (2004). Empowerment of rural women In Bangladesh: A Household Level Analysis, Conference On Rural Poverty Reduction Through Research And Transformation, DcutscherTropentag- Berlin- Germany.

Rahman, M. H., \& Naoroze, K. (2007). Women empowerment through participation in aquaculture: Experience of a large-scale technology demonstration project in Bangladesh, Journal of Social Science, volume,2, pp. 164-171.

Rowlands, Jo. (1995). Questioning Empowerment. Working with women in Honduras. London: Oxfam United Kingdom

Shah, S. (2015). Sociocultural Issues in Learning English for Women in Northwest Pakistan (Doctoral dissertation, Freie Universität Berlin).

Skarlatos, k. (2004).Microfinance and Women.s Economic Empowerment. Bridging the Gap, Redesigning the Future..Working Paper No 1, Wisconsin Coordinating Council in Nicaragua.

Sukontamam, P. (2007). Micro-credit, fertility decisions, and women's empowerment in Bangladesh, working paper No 94, University of Adelaide.

Swain, R. B., \&Wallentin, F. Y. (2007). Does microfmance empower women? Evidence from Self Help Groups in India, working paper No.24, department of economics, Uppsala University, August 2007

Swain, R.B. (2007a). Can Microfinance Empower Women? Self Help Group in India, Department of Economics, UPPSALA University, ADAN.37

Swain, R.B. (2007b). Does Microfinance Empower Women? Evidence from Self Help Group in India, Working Paper No. 24, UPPSALA University, Department Of Economics.

Todaro, M.P. (2003). Economic Development. Eighth Edition, Addison Wesley Longman, Singapore. 
Umashankar, D. (2006). Women's empowerment: Effect of participation in self-help groups.UNDP Report. (2008).

World Health Organization (WHO).(1995). Presentation to the Fourth World.Conference on Women. Beijing, China.

Zubia Mumtazand Sarah Salway (2005), "I never go anywhere': extricating the links between women's mobility and uptake of reproductive health services in Pakistan", Social Science \& Medicine, 60 (8), 17511765. 